\title{
Lean Manufacturing Achieved by Implanting Kanban at Supplier End
}

\section{Suraj S Abhale ${ }^{1 *}$ and Saurabha Masurkar ${ }^{2}$}

${ }^{1}$ Consultant for Savoir Faire, Maharashtra, India

${ }^{2}$ Trimurti Enterprises, Pune, Maharashtra, India

\begin{abstract}
Planning for the delivery of a product to customers becomes more efficient and demand from customers becomes more stable. Lean manufacturing is a set of tools and techniques and has been widely adopted by many production companies. A more continuous flow results in items being moved immediately from one workstation to the next as soon as they are ready. Lean manufacturing is a performance based process used in manufacturing organizations to increase competitive advantage. The basics of lean manufacturing employ continuous improvement processes to focus on the elimination of waste or non-value added steps within an organization.

We had shown the problems what can be appear in a M.S Industrial Components Pvt. Ltd company because of the overproduction. To affect inventory reductions, it is important to understand that inventory is created largely due to the variation that exists in the manufacturing system and that this variation. The Kanban lean manufacturing tool lets a company not only to save money but also allows reducing the lead time. All that finally, will make flexible and responsive as a business.
\end{abstract}

Keywords: Inventory; Continuous flow; Plan for delivery; Elimination of waste; Lean manufacturing

\section{Introduction}

The Kanban is used to signal the need for replacing or refilling materials necessary for production. There are a variety of ways that the signal can be sent. Actual cards, that a company goods though the production process can be used to keep track of current inventory [1]. However, something as simple as the arrival of an empty container at an upstream processing station is a clear signal that the parts that were in the container have been used and more. Kanban can be used in manufacturing systems where the product is manufactured to the pull of market demand.

It is the pull signal to produce. Once the product is withdrawn by the customer, at that moment the Kanban tells us exactly what the customer is using, and hence what the customer will need later. This Kanban is sent as fast as possible to the production line. In essence, the Kanban system is doing the "talking" to the production system, telling it to produce because some product has been removed. This system easily bypasses all the accounting and planning systems that tend to not only delay this signal but also add variability along the way. The Kanban system is dealing real time with the realities of what is happening on the line. Second, Kanban creates an absolute limit on total inventory. Since each Kanban represents a certain amount of stock, and the number of Kanban are strictly controlled and limited, this creates an upper limit on the inventory [2].

\section{Pull production focus}

A Kanban card can be generated to identify production of part(s) to replenish in-house inventories, a withdrawal of product for shipment to a customer, or to signal the replacement of raw materials and components. Using Kanbans there must be a purchase or an order to generate the card. The product is pulled through the production sequence based on the order from the customer. Pull Kanban is a part of the Lean Production or Just-in-time (JIT) manufacturing process, applying Lean principals to eliminate waste. Reduction of waste ensures lower costs, higher quality products, and delivery of waste ensures lower costs, higher quality products, and better service and delivery [3].

\section{Pull vs. push}

The pull system is the center of any synchronized factory; it works by working backwards, using signals or cards to trigger or start production. The process starts at the finished products warehouse or the shipping area.When a customer orders a product, the process triggers the previous operation to replace it; signaling more products is needed. The process continues backward through the factory to where raw materials are withdrawn which in turn triggers the supplier to ship the raw materials [4].

\section{Production challenges}

In today's global economy consumer are demanding quicker turnaround times along with a larger variety of quality products and specific features. Being able to predict variations in customer demands makes forecasting a complex process. This makes it nearly impossible to provide the products, or predict, what the consumer will request. The pull system eliminates the guesswork by making the consumers order the trigger to start production [5] (Figure 1).

\section{Purpose}

If the demand for products always stayed the same, companies could operate at maximum efficiency, producing only what was required and no more. When there is a smaller batch of work to be done, one of two things can happen; the underutilization of people, machines, or materials or overproduction. The board below shows a situation where the developers and analysts are being prevented from taking on any more work until the testers free up a slot and pull in the next work item.

*Corresponding author: Suraj S Abhale, Consultant for Savoir Faire, Maharashtra, India, Tel: 0222784 0509; E-mail: surajabhale.abhale@gmail.com

Received June 29, 2015; Accepted August 19, 2015; Published August 21, 2015

Citation: Abhale SS, Masurkar S (2015) Lean Manufacturing Achieved by Implanting Kanban at Supplier End. Ind Eng Manage 4: 171. doi:10.4172/21690316.1000171

Copyright: (c) 2015 Abhale SS, et al. This is an open-access article distributed under the terms of the Creative Commons Attribution License, which permits unrestricted use, distribution, and reproduction in any medium, provided the original author and source are credited. 


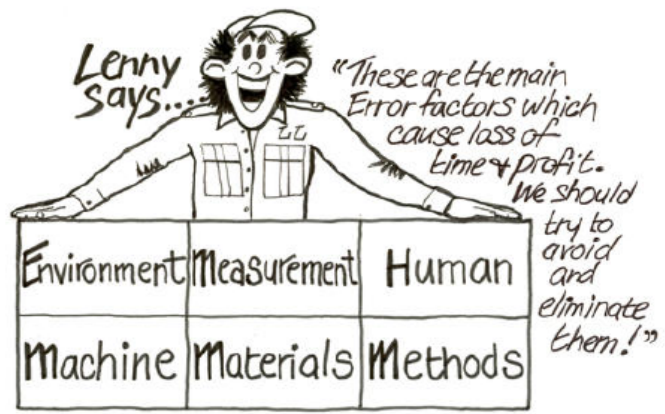

Figure 1: Factors to cause of loss [3].

\begin{tabular}{|c|c|c|c|c|c|c|}
\hline 6 & & & & & 3 & 5 \\
\hline Pending & & & Deve & oment & Test & Deploy \\
\hline & Doing & Done & Doing & Done & & \\
\hline & & $\square$ & & & $\square$ & \\
\hline & & $\square$ & & & 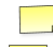 & \\
\hline & & $\square$ & & & $\square$ & \\
\hline & & & & & & \\
\hline
\end{tabular}
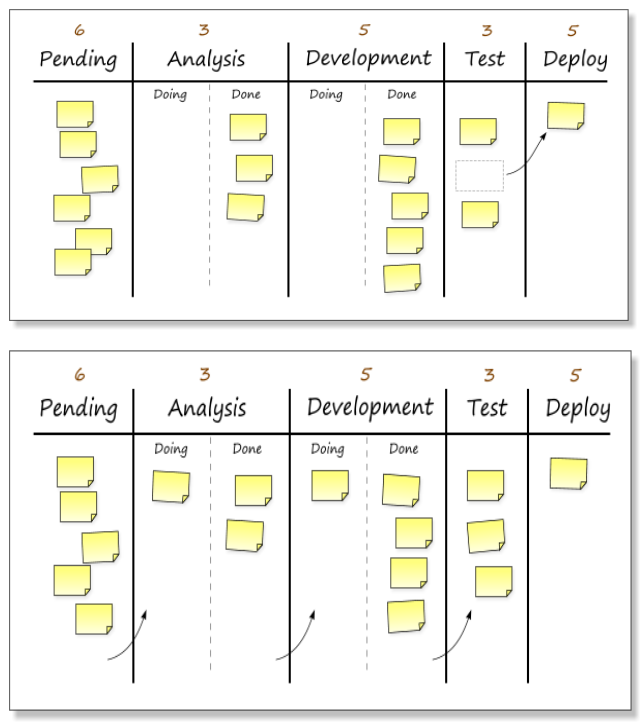

Figure 2: Work Division in different columns.

Notice that we've split some of the columns in two, to indicate items being worked on and those finished and ready to be pulled by the downstream process. Once the testers have finished testing a feature, they move the card and free up a slot in the "Test" column [6].

Now the empty slot in the "TEST" column can be filled by one of the cards in the development "DONE" column. That frees up a slot under "Development" and the next card can be pulled from the "Analysis" column [6] (Figure 2).

\section{Case Study of Reliable Auto-tech Pvt. Ltd.}

\section{Company requirement}

The part which is bought out from the supplier of M.S Industries for this parts company wanted to set up kanban system at M.S Industries i.e. at supplier end (Figure 3).

\section{Seven rules for using Kanban effectively}

1. Start with a Plan.

The PFEP (Plan for Every Part) is the cornerstone of the Kanban Card Implementation.

2. Order Only What You Need.

Customer processes order goods in the precise amounts specified on the Kanban.

3. Make Only What is Ordered.

Supplier processes produce goods in the precise amounts and sequence specified by the Kanban.

4. Kanban is Official.

No items are made or moved without a Kanban.

5. Material w/o Info is Trouble.

All parts and materials always have a Kanban attached.

6. Quality is \#1.

Defective parts and incorrect amounts are never sent to the next process.

7. Goal is $\mathrm{EOQ}=1$.

The numbers of Kanban is reduced carefully to lower inventories and reveal problems.

Step 1: PFEP - Plan for Every Part: Bought out parts supplied by M/S M.S Industries to Reliable Auto-tech Pvt. Ltd (RAPL) (Table 1).

Rules Considered While Implementing Kanban is shown in Table 2.

Step 2: Part selected for Kanban implementation: Maximum repetitive required part which are selected for implementation of Kanban (Figure 4).

\section{Required data collection}

1. Average Daily Demand (D)

2. Lead Time (L)

3. Safety Coefficient (S)

4. Container Capacity ( $\odot$

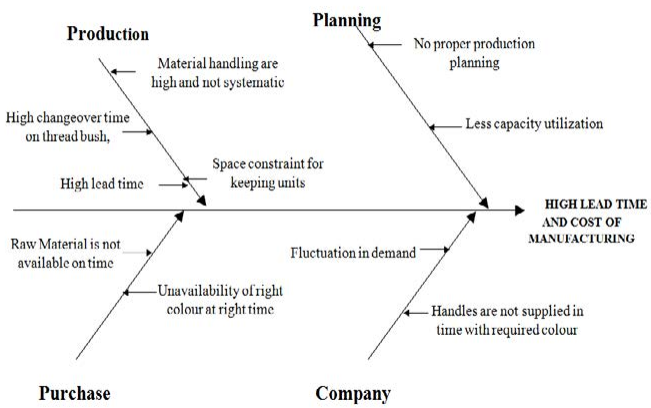

Figure 3: Fishbone diagram [4]. 


\begin{tabular}{|c|c|c|}
\hline Description & $\begin{array}{l}\text { Average Monthly } \\
\text { Demand }\end{array}$ & $\begin{array}{c}\text { Average Daily } \\
\text { Demand }\end{array}$ \\
\hline $\begin{array}{l}\text { PIN HING FOR HOD } \\
\text { Flapper(5550320R1) }\end{array}$ & 2500 & 100 \\
\hline Threaded Bush(008000304B1) & 15200 & 608 \\
\hline Axe Emelturl & 10000 & 400 \\
\hline Boss Tapped JD-4 & 200 & 8 \\
\hline Counter Shaft JD-4 & 200 & 8 \\
\hline Hub JD10 & 160 & 6 \\
\hline Hub JD10 & 520 & 21 \\
\hline Hub JD10 & 620 & 25 \\
\hline Bushing Pivot JD10 & 640 & 26 \\
\hline Hub Jd10 & 580 & 23 \\
\hline HUB JD10 P1 (Without Keyway) & 216 & 9 \\
\hline HUB JD10 P1 (With Keyway) & 216 & 9 \\
\hline Bushing Stepped (JD6) & 1500 & 60 \\
\hline Actuator (JD6) & 1500 & 60 \\
\hline Step Bush For JD06 Assembly & 4000 & 160 \\
\hline Bushing For JD06 Assembly & 2000 & 80 \\
\hline Bushing For JD06 Assembly & 0 & 0 \\
\hline Washer Hinge(JD12) & 400 & 16 \\
\hline Pin For Jd-6 & 100 & 4 \\
\hline Roller & 2000 & 80 \\
\hline Roller & 2000 & 80 \\
\hline Sleeve & 2000 & 80 \\
\hline
\end{tabular}

Table 1: Bought out parts supplied by M.S Industries.

\begin{tabular}{|l|l|l|}
\hline $\begin{array}{l}\text { Rule } \\
\text { No. }\end{array}$ & Rule & Function \\
\hline 1 & $\begin{array}{l}\text { Later process goes to earlier process } \\
\text { andpicks up the number of items } \\
\text { indicated by the Kanbans }\end{array}$ & $\begin{array}{l}\text { Creates pull, provide pick up } \\
\text { or transportation information. } \\
\text { The replenishment concept is } \\
\text { formatted here. }\end{array}$ \\
\hline 2 & $\begin{array}{l}\text { Earlier processes produce items in a } \\
\text { quantity and sequence indicated by the } \\
\text { Kanbans }\end{array}$ & $\begin{array}{l}\text { Provides production information } \\
\text { and prevents overproduction. }\end{array}$ \\
\hline 3 & $\begin{array}{l}\text { No items are made or transported } \\
\text { without a Kanbans. }\end{array}$ & $\begin{array}{l}\text { Prevents overproduction and } \\
\text { cessivetra nsportation. }\end{array}$ \\
\hline 4 & $\begin{array}{l}\text { Always attach a Kanbans to the goods. } \\
\text { Serves as a work order. }\end{array}$ \\
\hline 5 & $\begin{array}{l}\text { Defective products are not sent to } \\
\text { thesubsequent process. }\end{array}$ & $\begin{array}{l}\text { Prevents defective parts from } \\
\text { advancing:identifies defective } \\
\text { process. }\end{array}$ \\
\hline 6 & $\begin{array}{l}\text { Reducing the number of Kanbans } \\
\text { increases their sensitivity. }\end{array}$ & $\begin{array}{l}\text { Inventory reduction reduces } \\
\text { waste and makes } \\
\text { the system more sensitive. }\end{array}$ \\
\hline
\end{tabular}

Table 2: Rules and Function [7]

\begin{tabular}{|c|c|c|}
\hline $\begin{array}{c}\text { Sr } \\
\text { No }\end{array}$ & Name Of Part & Figure \\
\hline 1) & Thread bush & \\
\hline 2) & Step bush & \\
\hline 3$)$ & Axe Emeltur & \\
\hline & & \\
\hline
\end{tabular}

Figure 4: Part selected for Kanban implementation.
We saw problems what can be appear in a company because of the overproduction. To affect inventory reductions, it is important to understand that inventory is created largely due to the variation that exists in the manufacturing system and that this variation [7] (Table 3).

\section{Implementation of Kanban}

- Value Stream Mapping.

- Current State

- Future State

- Planning both material flow and information flow.

- PFEP - Plan for Every Part

- Racks and Bins - Place for Every Part

- Kanban is like the tip of the iceberg: it is the highly visible portion [6]

We considered first thread bush the steps which are shown for the thread bush those are also considered for the STEP BUSH

Capacity calculation of $M / S$ industry supplied parts considering their lead time

Capacity Calculation of M/S Industry Supplied Parts Considering Their Lead Time is shown in Tables 4-6.

Formulae:

1) No of Kanban Cards $=$ Avg Daily Demand ${ }^{\star}(1+\alpha)^{\star}$ Lead Time/ Container Capacity

2) Minimum Lot Size $=\operatorname{Demand}^{*}(1+\alpha) / \operatorname{Avg}$ No of Set Up

3) No of Containers = Kanban Quantity/No of Parts Held Per Container

4) Kanban Quantity $=$ Weekly Part Usage ${ }^{\star}$ Lead Time ${ }^{\star}$ No Of Locations ${ }^{*}$ Smoothing Factor [7] (Figure 5).

\begin{tabular}{|l|l|c|c|c|c|}
\hline Part & Part code & $\begin{array}{c}\text { Lead Time } \\
\text { (days) }\end{array}$ & $\begin{array}{c}\text { Avg Daily } \\
\text { Demand }\end{array}$ & $\begin{array}{c}\text { 6 Day } \\
\text { Demand }\end{array}$ & $\begin{array}{c}\text { Container } \\
\text { Capacity }\end{array}$ \\
\hline Thread bush & OBO0202A40007 & 6 & 350 & 2100 & 700 \\
\hline Step bush & OBO113671 & 9 & 240 & 1440 & 800 \\
\hline Axe emeltur & OBOZ001064X01 & 9 & 500 & 3000 & 1500 \\
\hline
\end{tabular}

Table 3: Data Collection.

\begin{tabular}{|l|c|c|c|c|c|c|}
\hline Operation & $\begin{array}{c}\text { Cycle Time } \\
\text { (sec) }\end{array}$ & $\begin{array}{c}\text { Working } \\
\text { Time (hr) }\end{array}$ & $\begin{array}{c}\text { No. } \\
\text { of M/C }\end{array}$ & $\begin{array}{c}\text { OEE } \\
\text { (\%) }\end{array}$ & $\begin{array}{c}\text { Thread Bush 6 } \\
\text { day Capacity }\end{array}$ & $\begin{array}{c}\text { Set Up } \\
\text { Time (min) }\end{array}$ \\
\hline Traub & 60 & 20 & 1 & 80 & 5760 & 120 \\
\hline ID chamfer & 25 & 8 & 1 & 80 & 2304 & 20 \\
\hline Tapping & 20 & 8 & 1 & 80 & 2304 & 20 \\
\hline
\end{tabular}

Table 4: Capacity of thread bush production in 6 days.

\begin{tabular}{|l|c|c|c|c|c|c|}
\hline Operation & $\begin{array}{c}\text { Cycle } \\
\text { Time } \\
(\mathbf{s e c})\end{array}$ & $\begin{array}{c}\text { Working } \\
\text { Time } \\
\mathbf{( h r )}\end{array}$ & $\begin{array}{c}\text { No Of } \\
\text { M/C }\end{array}$ & $\begin{array}{c}\text { OEE } \\
\mathbf{( \% )}\end{array}$ & $\begin{array}{c}\text { Step Bush } \\
\mathbf{6} \text { day } \\
\text { Capacity }\end{array}$ & $\begin{array}{c}\text { SetUp } \\
\text { Time } \\
\text { (min) }\end{array}$ \\
\hline Traub and Drill & 120 & 20 & 1 & 80 & 2880 & 120 \\
\hline $\begin{array}{l}\text { Stress } \\
\text { Relieving }\end{array}$ & 20 & 20 & 1 & 80 & 17280 & \\
\hline OD Grinding & 15 & 20 & 1 & 80 & 23040 & 10 \\
\hline $\begin{array}{l}\text { Facing } \\
\text { Turning }\end{array}$ & 180 & 20 & 2 & 80 & 3840 & 90 \\
\hline
\end{tabular}

Table 5: Capacity of step bush production in 6 days. 


\begin{tabular}{|l|c|c|c|c|c|c|}
\hline Operation & Cycle Time (sec) & Working Time (hr) & No of M/C & OEE (\%) & Axe emultor 6day Capacity & Set Up Time (min) \\
\hline Traub Drill & 60 & 20 & 1 & 80 & 5760 \\
\hline CNC first Operation & 90 & 20 & 1 & 80 & 3840 \\
\hline CNC second Operation & 90 & 20 & 1 & 80 & 3840 \\
\hline Drill & 60 & 20 & 1 & 80 & 5760 \\
\hline ID Chamfer & 35 & 20 & 1 & 80 & 90 \\
\hline
\end{tabular}

Table 6: Capacity of Axe Emeltur production in 6 days.

\begin{tabular}{|c|c|c|c|}
\hline Part Name & Min Stock & Safety Stock Level & Card Qty \\
\hline Threaded Bush & 2100 & 4200 & 700 \\
\hline Axe Emelturl & 3000 & 6000 & 700 \\
\hline Step Bushing & 1600 & 3200 & 500 \\
\hline
\end{tabular}

Table 7: Stock Level Consideration.

\section{Implementation of Kanban}

- Value Stream Mapping

- Current State

- Future State

- Planning both material flow and information flow

- PFEP - Plan For Every Part

- Racks and Bins - Place for Every Part

- Kanban is like the tip of the iceberg: it is the highly visible portion [8].

We considered first thread bush the steps which are shown for the thread bush those are also considered for thread bush if starting finished good stock is about 9 cards that is 6300 no each week there is 3 card consumption of thread bush in M/S Industry (Table 7).

\section{OUTSOURCE OPERATION}

OPERATION at II ND PLANT

\section{Kanban for thread bush}

1. Avg Daily Demand (D) $=350$

2. Lead Time $(\mathrm{L})=6$ days for 2100 parts

We considered 2100 parts because of there is tapping operation which is outsource from other supplier and due to transportation, their machine availability ,and no of worker required for the loading and unloading the part, and no of set ups we are took the 3 card quantity to production.

And also for the traub operation in M/S industry the setup time required i.e. 2 hours for the traub and machine availability for traub, and capacity to produce the parts in a day is about 5800 .

3. Safety Coefficient (S): $( \pm 20 \%)$

4. Container Capacity (C)

If card $=9$ for thread bush and card quantity is 700 .

WIP stock $=($ Demand of each week $)$ after each 1 week i.e. after 6th card.

Initial stock: At the first stage of implementation of thread bush there is 9 cards stock in 1 finished goods i.e 6300 nos.

After first week: 3 cards are consumed, and 3 cards goes to

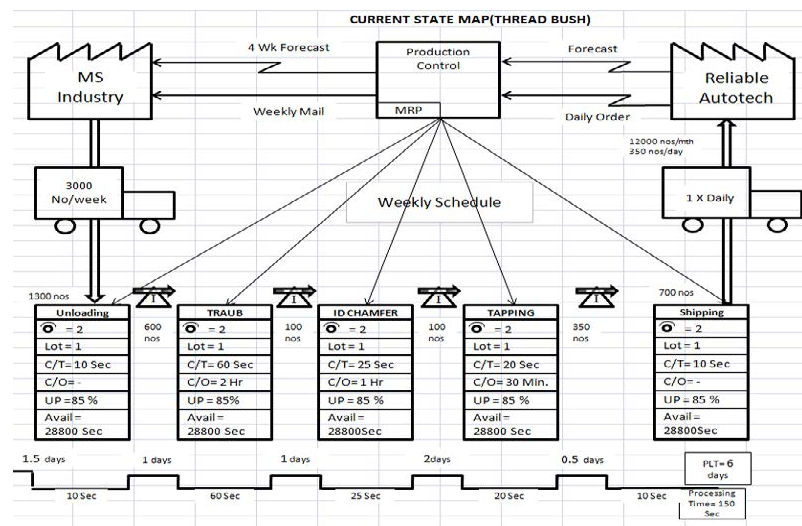

Figure 5: Value Stream Map of Thread Bush.

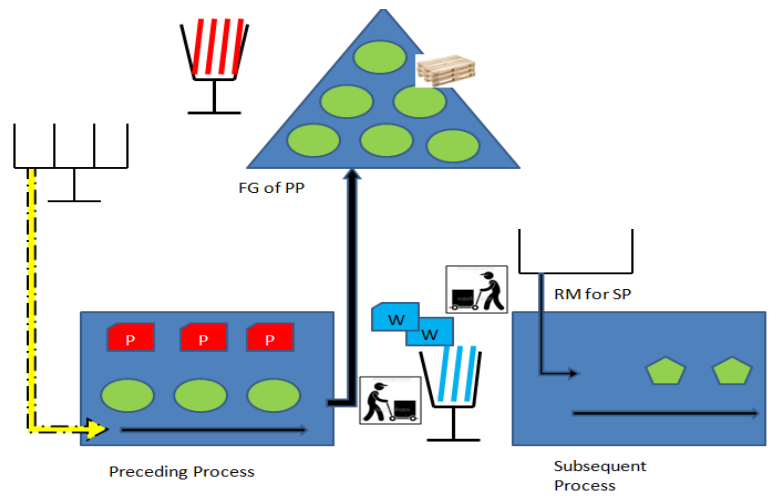

Figure 6: Card movement for the production process.

preceding process then production starts remaining stock $=4200$ nos.

After second week: The cards which are goes to preceding process are now ready to replenish and 3 card are to dispatch to customer (Reliable) (Figure 6).

Finished Good kanban card Board is shown in Figure 7.

\section{Conclusion}

From the successful implementation of Kanban system of those three parts (Thread Bush, Axe Emulator, Step Bush) the problem 


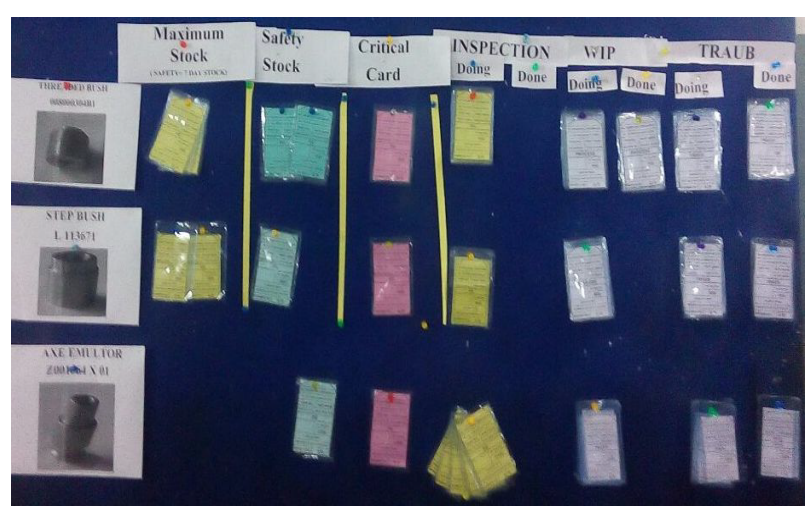

Figure 7: Finished Good kanban card Board.

related with overproduction, or out of stock, lack of raw material, are so reduce. As the system in the Reliable Autotech is going on the major parts which are supplied by M/S Industry is now be implement this system to their other parts. The Kanban system provides a company the following positive results:

- Employees know exactly what is required based on the conditions in the workplace.

- Employees do not need to be assigned a job; they are allowed to perform work when and where it is needed.
- Unnecessary paperwork is eliminated and the possibility of making an error is reduced.

- The skill level of employees is increased and the variety gives them more satisfaction from their work.

\section{References}

1. Apreutesei M, Arvinte IR, Suciu E, Munteanu D (2010) Application of Kanban System For Managing Inventory. Bulletin of the Transilvania University of Brasov 3: 161.

2. Rubrich L, Watson M (1998) Implementing world class manufacturing. Fort wayne, in: WCM associates.

3. Abdul Rahmana NA, Mohd Sharifb S, Mohamed Esac M (2013) Lean Manufacturing Case Study with Kanban System Implementation. Procedia Economics and Finance 7: 174-180.

4. Naufal A, Jaffar A, Yusoff N, Hayati N (2012) Development of Kanban System at Local Manufacturing Company in Malaysia Case. Procedia Engineering 41: 1721-1726.

5. Junior ML, Filho MG (2010) Variations of the Kanban system: Literature review and classification. Int. J Production Economics 125: 13-21.

6. Chan FTS (2001) Effect of kanban size on just in time manufacturing systems. Journal of materials processing technology 116: 146-160.

7. Takahashi K, Nakamura N (2002) Decentralized reactive Kanban system. European Journal of Operational Research 139: 262-276.

8. Al-Tahata MD, Mukattashb AM (2006) Design and analysis of production control scheme for Kanban-based JIT environment. Journal of the Franklin Institute 343: 521-531. 